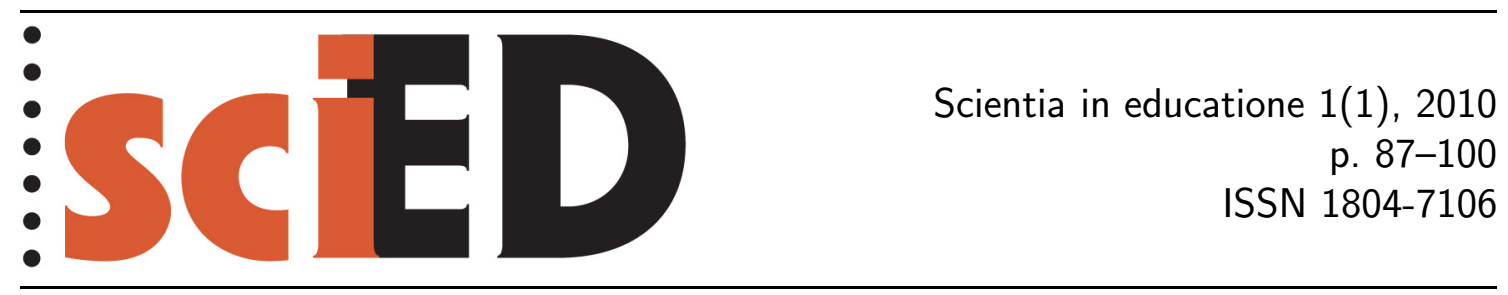

\title{
Zdroje epistemologických překážek v porozumění nekonečnu
}

\author{
Magdalena Krátká
}

\begin{abstract}
Abstrakt
Článek analyzuje tři oblasti jevů, se kterými se setkáváme ve snaze identifikovat epistemologické překážky v porozumění nekonečnu: Pojetí existence a s tím související princip tvůrce, Obzor a jeho polohy a Znalosti o konečnu. Každou z těchto oblastí podrobně popisuji a ilustruji jednotlivé jevy výňatky z experimentálních rozhovorů. Na závěr je uvedena diskuse o těchto třech oblastech a důsledky z toho plynoucí pro hledání konkrétních epistemologických překážek.
\end{abstract}

Klíčová slova: nekonečno, epistemologická překážka, obzor, princip tvůrce.

\section{Sources of Epistemological Obstacles in Understanding Infinity}

\begin{abstract}
The article analyzes three areas of phenomena with which we meet in our effort to identify epistemological obstacles in understanding infinity - Conception of the Objects Existence and related creator's principle, The Horizon and its Positions, and Knowledge of Finity. Each of the areas is described in detail. Further particular phenomena are illustrated by extracts of experimental interviews. Finally the discussion on these three areas and subsequences in finding specific epistemological obstacles follows.
\end{abstract}

Key words: infinity, epistemological obstacle, horizon, the creator's principle. 


\section{1 ÚVOD}

Nekonečno, at to matematické, filozofické nebo teologické, fascinovalo a fascinuje lidstvo od počátků utváření vědeckého myšlení dodnes. Mnozí matematici se nechali omámit slastným pocitem toho, kdo rozřešil záhadu, při filozofování nad problémy založenými na nekonečnu. Stejný pocit mohou zažít dnešní studenti, když znovu objevují překvapivé vlastnosti nekonečného.

Rozvíjení poznatků o nekonečnu tvoří v historii matematiky ve všech kulturách zásadní mezníky důležité pro její další vývoj. V posledních více než třiceti letech byla otázka učení a výuky témat souvisejících s nekonečnem, popřípadě otázka porozumění nekonečnu samotnému, v centru zájmu mnoha výzkumníků didaktiky matematiky. ${ }^{1}$ Panuje všeobecná shoda, že nekonečno je klíčovým pojmem poznávacího procesu a že zasluhuje hlubší analýzu v rámci kognitivní psychologie (Fischbein et al., 1979).

Ve výzkumném týmu pracujícím na katedře matematiky PřF UJEP v Ústí nad Labem jsme se proto před několika lety rozhodli zaměřit výzkum na srovnání ontogenetického a fylogenetického vývoje porozumění nekonečnu. Za výchozí paradigma jsme zvolili teorii epistemologických překážek, která nabízí účinný aparát pro využití poznatků o historickém vývoji pojmu nekonečna při studiu vývoje porozumění tomuto jevu jedincem.

Vzhledem $\mathrm{k}$ tomu, že nekonečno má mnoho různých projevi̊, bylo třeba tuto splet nejprve nějak strukturovat, tedy vyčlenit nejdůležitější z oněch projevů, jeho atributy. Soustředili jsme se na následujících šest atributů: mohutnost množiny, omezenost množiny, míra množiny, uspořádání, nekonečný proces a konvergence. Avšak při hledání překážek souvisejících s těmito nejrůznějšími atributy jsme naráželi na stále stejné jmenovatele. Ty jsme nakonec označili za hlavní zdroje epistemologických překážek porozumění pojmu nekonečno (a nejen jemu).

V následujících částech nejprve stručně vymezím pojem „epistemologická překážka“. Poté ve třech paragrafech podrobněji rozeberu zdroje epistemologických překážek - pojetí existence a s tím související princip tvůrce, obzor a jeho polohy zabývající se přirozeným a klasickým nekonečnem a znalosti o konečnu, které vystupují jako překážka v nejrůznějších kontextech souvisejících se všemi zmiňovanými atributy.

\section{EPISTEMOLOGICKÉ PŘEKÁŽKY}

Základním teoretickým východiskem je teorie epistemologických překážek, kterou formuloval G. Brousseau a která byla postupně rozpracována až do teorie didaktických situací (Brousseau, 1997; Brousseau, Sarrazy, 2002). Teorie epistemologických překážek navazuje na Piagetovu teorii vývojových stádií. Zde se ale navíc předpokládá, že konstrukce poznání není určena jen pozitivními stadii, jak to formulovali Piaget a Garcia, ale také prostřednictvím „negativních“ stádií, zahrnujících různá pravidla, přesvědčení a způsoby uvažování, jež vytvářejí překážky pro změny vedoucí k dalším stádiím (Sierpinska, 1994).

Překážku chápeme jako soubor znalostí ukotvených ve znalostní struktuře jedince, které lze v určitých situacích úspěšně použivat, ale v novém kontextu selhávají a dávají špatné výsledky.

\footnotetext{
${ }^{1}$ Pro ucelený přehled je možné nahlédnout do dvojčísla 2-3 48. ročníku časopisu Educational Studies in Mathematics, které bylo celé věnováno nekonečnu.
} 
Překážka se projevuje jako chyba, která odolává sporům, s nimiž je konfrontována, a tak zabraňuje vytvoření „lepší znalosti. Objevuje se stejným zpơsobem, kdykoli se jedinec dostane do obdobné situace ${ }^{2}$. Často ji pozorujeme u významné části populace ${ }^{3}$, nebo se opakuje v historii nějakého pojmu či pojetí. Překážka má tendenci se lokálně přizpůsobit $\mathrm{s}$ tím, že ona sama je měněna, jak nejméně je to možné. Důvodem je skutečnost, že překážka je znalost vztahující se k nějakému pojmu, tj. k matematickému pojmu. Ten vždy souvisí s celou skupinou významů a s mnoha nástroji, tvrzeními a algoritmy, které jedinec při práci s tímto pojmem může používat. Překážka je překonávána, až když je nová znalost upevněna ve znalostní struktuře jedince, což je dlouhodobý proces, nebot překážka souvisí s celou množinou situací, kdy tato znalost (tj. překážka) dává smysl (Brousseau, 1997; Radford, 1997; Spagnolo, Čižmár, 2003). V pojetí didaktické rekonstrukce jde o přebudování celého modelu, kdy je nový model konstruován na základech stávajícího a jedinec „opravuje“ to, co je nezbytné pro fungování modelu v nové situaci. Proto není možné jednoduše přebrat obsahy jednotlivých matematických disciplín jako takových (byt' po příslušném zjednodušení a modelování), ale je nutné jejich znovuvytvoření na základě individuálních zkušeností (Kapadia, Borovcnik, 1991; Jelemenská et al., 2003).

Překážky epistemologického původu se vztahují k samotnému procesu nabývání znalostí. Jsou to překážky, kterých se nemůžeme a ani bychom se neměli vyvarovat, nebot mají fundamentální formativní funkci pro danou znalost. Právě ty můžeme nalézt v historii samotného pojmu (Brousseau, 1997).

Brousseaův př́stup je založen na předpokladu, že znalost může existovat a dávat smysl pouze tehdy, pokud představuje optimální řešení v daném systému daných skutečností. Historické studie tak mohou být inspirující právě pro zjištění, které nutnosti musely být změněny pro vznik či vývoj nové matematické znalosti. V tomto pojetí není tak znalost stavem mysli, je to vlastně řešení nějakého problému, které je nezávislé na řešiteli ${ }^{4}$. Z tohoto pohledu jsou epistemologické překážky zdrojem opakujících se nenáhodných chyb, jichž se jedinec dopouští při řešení odpovídajících problémů. Epistemologická překážka je něco, co zcela náleží pojmotvornému procesu (Radford, 1997; Radford et al., 2000).

\section{Metodologie}

V následujících paragrafech jsou pro ilustraci popisovaných jevů užity rozhovory, které vznikaly v rámci dlouhodobého výzkumu o vývoji představ o nekonečnu, popř́padě v rámci disertační práce (Krátká, 2009). Ř́izené experimentální rozhovory byly realizovány s respondenty ve všech věkových kategoriích od 9 do 19 let a doplněny byly rozhovory s vysokoškolskými studenty - budoucími učiteli matematiky. Vždy byly zaznamenávané videokamerou. Záznamy byly po přepisu do protokoli̊ podrobně analyzovány. Pozornost byla zaměřena zejména na formulaci překážek v porozumění nekonečnu a na proces jejich překonávaní. Při sestavování přibližných scénářů experimentálních rozhovorů jsme používali metodu konstruované reakce žáků. V analýzách rozhovorů jsme sledovali navození kognitivního konfliktu a pokusy o jeho odstranění. (Více o této metodě v článku Cihlář et al., 2009).)

\footnotetext{
${ }^{2}$ Zde můžeme postihnout rozdíl mezi překážkou a obtíží. Obtíž není způsobena jinou znalostí, ale neznalostí nebo chybějící dovedností apod. Je-li jednou překonána, už se neopakuje. (Zde pochopitelně není řeč o zapomínání.)

${ }^{3}$ Učitelé popisují tento jev jako „děti obvykle dělají tuto chybu“.

${ }^{4}$ Je nutné zdůraznit, že zde je řeč o znalostech ve smyslu idejí, např. matematických pojmů, nikoli o znalostech jedince, které jsou chápány jako na něm závislé.
} 


\section{HLAVNÍ ZDROJE EPISTEMOLOGICKÝCH PŘEKÁŽEK}

Na základě dlouhodobého výzkumu a předcházejících studií (Krátká, 2009; Cihlář et al., 2009) jsme vymezili dva hlavní zdroje epistemologických překážek - Pojetí existence a Obzor a jeho polohy. $\mathrm{K}$ nim lze účelně přiřadit další oblast, kde shledáváme původ mnoha překážek souvisejících s utvářením představ o nekonečnu Znalosti o konečnu. Tyto tři oblasti nejsou disjunktní, naopak jsou rozmanitě propojené a jednu od druhé nelze oddělit. Kritériem rozdělení na tyto tři oblasti je tedy hlavně úhel pohledu a zaměření pozornosti na určité jevy provázející proces utváření porozumění nekonečnu; a to takové, které nacházíme jak u jednotlivých žáků a studentů, tak v historii samotného pojmu.

\subsection{Pojetí EXISTENCE - PRINCIP TVŮRCE}

Pro zdárný průběh učebního procesu má klíčovou roli zjištění toho, jak ten či onen žák chápe existenci objektı̊ zkoumaných vědou. Jinými slovy, jakou modalitu bytí těmto jevům žák přisuzuje. Přitom př́ipadné poopravení těchto žákových názorů patří mezi významné cíle celého učebního procesu.

Evropská věda volí podle vzoru antické geometrie za hlavní nástroj zkoumání reálného světa ideální, ostrý a strnulý svět, podložený pod světem reálným. Tento ideální svět se pak postupně stává vlastním předmětem jejího zkoumání, kdežto svět reálný je místem, na něž věda přenáší poznatky získané ve světě ideálním. Bytí nějakého objektu reálného světa má jinou modalitu než bytí ideálního objektu pod něj podloženého. Objektivní existence ideálních abstraktních objektů je tedy vázána na bytí objektů reálných. Bytí ideálních objektů bývá vykládáno dvojím způsobem. Při platónském pojetí je trvalé (nečasové), objekty existují nezávisle na tom, zda je někdo nazírá. Při eukleidovsko-aristotelovském pojetí jsou tyto objekty vykládány jako abstrakce z objektů reálných. Platónské pojetí v matematice začalo převládat až začátkem dvacátého století, po nástupu teorie množin.

Různost modalit bytí reálných či ideálních objektů je třeba brát v úvahu při učebním procesu. Děti na počátku učebního procesu přistupují k jevům naprosto subjektivně. Přisuzují existenci těm objektům, které mohou evidovat tělesnými smysly, a to bezprostředně. Například zeptáme-li se dítěte, zda nějaká daná úsečka $A B$ má střed, odpoví, že ne, dokud není tento střed sestrojen. Tedy ted’ úsečka střed nemá, ale za chvíli by ho mohla mít. Aby ho měla, bud' musí být již sestrojen anebo ho musí (fyzicky) dítě sestrojit. Tuto potřebu vykonání nazýváme principem tvưrce. Popsaná situace nás však upozorňuje ještě na jeden fakt, totiž že dítě rozumí bodu jako oné čárce na obrazu úsečky, popřípadě přímce či úsečce jako jejímu obrázku. Mluvíme tak obecně o záměně objektu s jeho modelem.

V dalším stádiu jedinec na stejnou otázku už odpovídá, že úsečka střed má, ale další body nevidí, popřípadě jich vidí jen nějaký malý počet, zopakuje-li v myšlení konstrukci středu. Jde stále o princip tvůrce, i když v jeho zeslabené podobě. Jedinec totiž stále potřebuje vědět, jak se daný objekt vytvoří. Avšak už nemusí být oním tvůrcem, dokonce ani nemusí být objekt fyzicky sestrojen. Stačí, když je mu znám postup konstrukce. Pro takového jedince nemůže být na úsečce nekonečně mnoho bodů, nebot neexistuje postup, jakým by byly sestrojeny. (Navíc zde bude hrát roli i zmiňovaná záměna objektu s modelem.) Odpověd' takového dítěte lze pak charakterizovat vyjádřením $N a$ úsečce bude tolik bodů, kolik se jich tam vejde, asi tak 30. V jeho představě totiž probíhá proces konstrukce těchto bodů. Tento způsob uvažování lze přirovnat k uvažování Eukleidovu. Ten samozřejmě nepovažuje úsečku 
za množinu bodů. Body jsou pro něj bud' ty, které jsou významné (krajní body úsečky, vrcholy čtverce), nebo ty, které konstruuje.

Podobně se princip tvưrce může objevit, když dítě odpovídá na otázku, zda je nějaká (relativně početná) množina konečná či nekonečná. Jeho argumentace totiž stojí většinou na představě, že by on sám měl fyzicky spočítat prvky dané množiny. Není možné obecně říci, v jakém věku se dítě nachází v této fázi a kdy přechází do dalšího stádia, které můžeme popsat schopností jedince operovat s principielní možností spočítat prvky dané množiny. V experimentech jsem se setkala s devítiletými dětmi, které byly schopny v tomto kontextu uvažovat na abstraktní úrovni (tj. abstrahovat od nutnosti reálně proveditelného počítání prvků), a naopak s gymnazisty, kteř́i jsou stále principem tvưrce ovlivněni.

$\mathrm{V}$ případě geometrického kontextu se princip tvůrce projevuje následujícími možnými způsoby:

- Dítě pokládá za existující jen ten objekt (bod, úsečku apod.), který je bud' již zkonstruován, nebo ho musí samo zkonstruovat.

- Dítě pokládá za existující takový objekt, jehož konstrukce je mu známa (např. ví, jak zkonstruovat střed úsečky apod.). Akceptuje takové objekty, jež je on nebo jiný člověk schopen zkonstruovat (na úsečce je možné zkonstruovat vždy jen konečně mnoho bodů).

- Dítě připouští, že objekty mohou být principielně sestrojeny (může jich být tedy i potenciálně nekonečně mnoho).

I zde, v geometrickém kontextu, se princip tvůrce projevuje všemi zmiňovanými způsoby v různých věkových kategoriích. Např. ve svém výzkumu Jirotková a Littler (2003) uvádějí použití prvního zmiňovaného způsobu v úvahách studentů učitelství, tj. vysokoškoláků. Předchozí úvahy lze ilustrovat úryvky z experimentálních rozhovorů s jednotlivými žáky.

Jakub (11 let) řeší úlohu Kolik nejvíc bodů lze sestrojit na úsečce $A B$ a kolik na úsečce $C D$ ?, doprovozenou obrázkem s úsečkou $A B$ dvakrát delší než je úsečka $C D$. V několika odpovědích z následujícího rozhovoru se u něj objevuje přímá fixace na tento obrázek spojená s principem tvůrce, tj. objekty existují až tehdy, jsou-li vytvořeny (zkonstruovány). Zcela se soustředí jen na skutečnost, že by měl body narýsovat, opomíjí otázku po největším počtu bodů. Jakub na úsečce $A B$ vyznačil tužkou svislými čárkami 8 bodů, na úsečce $C D 4$ body a říká:

Jakub8: Na tý větši AB jich bude 8, po centimetru. A tady na tý menši 4, taky po centimetru.

Experimentátor9: ${ }^{5}$ Dobře. A šly by tam narýsovat ještě nějaké dalši body kromě těch, cos tam narýsoval?

J10: Jo. Třeba tady. (kreslí další body na úsečce $C D$ ) Takhle mezi tím.

E11: Hm. A kolik by jich šlo narýsovat nejvíc?

J12: Tak je nakreslím po milimetru.

E13: To by bylo nejvíc? Kolik by jich teda asi tak bylo?

J14: (kreslí a přemýšlí) Tři centimetry (4), po jednom milimetru (5), tak třicet.

E15: Třicet. To je nejvíc, co by šlo? Pak už by to nešlo?

J16: Ne.

Marek (13 let) řeší úlohu Kolik bodu leži na úsečce deset centimetrů dlouhé? V první reakci Marek pokládá za existující body jen ty, které jsou vyznačeny. Po

\footnotetext{
${ }^{5} \mathrm{~V}$ dalších záznamech rozhovorů je vždy experimentátor označen písmenem E, respondent iniciálou křestního jména. V reakcích jsou označeny číslem v závorce pauzy v řeči v sekundách.
} 
upozornění experimentátora si Marek uvědomí existenci středu úsečky, a je schopen svou úvahu zobecnit. Uskutečňovatelem již nemusí být on sám, ale někdo abstraktní, body mohou být sestrojeny pouze principiálně. Rychle pak připouští existenci nekonečně mnoha bodů.

E57: Kolik bodi̊ leží na úsečce deset centimetrü dlouhé?

M58: No dva, začínající bod a končící bod.

E59: To jsou teda jediný dva body, který leži na tý úsečce?

M60: $H m$, jo.

E61: A třeba střed, můžeš namalovat střed tý úsečky?

M62: Hm, tam můžu mít vlastně bod X (kreslí úsečku asi $7 \mathrm{~cm}$ dlouhou, vyznačuje na ní svislou čárkou krajní body a střed, který označuje jako $X$ ). Takže vlastně tam bude nekonečně mnoho těch bodů, na tý úsečce.

E63: A to bys zvládnul, nakreslit na tý úsečce nekonečně mnoho bodì, jo?

M64: No to ne, to bych ani nemohl, ale šlo by to, prostě pořád dál a dál u těch úseček kreslit ty jejich stredy.

Schopnost pracovat pouze s principielní možností zkonstruování bodi̊, a v důsledku tedy s potenciálně nekonečnou množinou (analogicky s pouze principielní možností spočítání prvků nějaké množiny), souvisí také s tím, jak posouváme náš obzor. O tom pojednává následující paragraf.

\subsection{OBZOR A JEHO POLOHY}

Matematika jako vědní obor pracuje již od starověku pouze s nekonečnem klasickým, tj. jasně vymezeným a nezávislým na jedinci. Oproti tomu přirozené nekonečno je jev subjektivní. Jedinci se může nějaká množina nebo objekt jevit nekonečným (tedy přirozeně nekonečným), jestliže se táhne až $\mathrm{k}$ jeho obzoru. Obzor je také pojem subjektivní - je to hranice našeho pohledu, at̉ už smyslového nebo „prodlouženého znalostmi“, a zároveň to je mez oddělující „viditelnou část světa od neviditelné". Překročíme-li nějaký obzor, znamená to, že rozššříme viditelnou část, a to, co se předtím jevilo jako nekonečné, se už nekonečným nejeví (Vopěnka, 2008).

Uvědomíme-li si přítomnost obzorů a možnost jejich překračování - nalezneme-li onen společný princip překonávání našich obzorů - objevíme klasické nekonečno. Tak k němu přistupoval Eukleides, když požadoval, aby jakákoli úsečka byla prodloužitelná tak, jak potřebujeme, nebo když formuloval tvrzení o množství prvočísel slovy Prvočisel je více než jakékoli dané množství. Vyslovil tak požadavek, že jakýkoli obzor může být překročen (Eukleides, 2007). Je zřejmé, že se v tomto př́padě jedná o nekonečno potenciální - neříká se totiž, že jsou již všechny obzory prolomeny. Takový prrístup se objevuje až v teologických úvahách středověku a do matematiky definitivně proniká aktuální (klasické) nekonečno až s teorií množin díky Bolzanovi, Cantorovi a jejich pokračovatelům, kteří si již směle mohli přisvojovat schopnosti křestanského Boha, což Bolzano i Cantor veřejně přiznali.

Oproti tomu se v případě přirozeného nekonečna setkáváme spíše s jeho podobou aktuální, protože množiny, které se táhnou až za naše obzory, již existují. S potenciálním přirozeným nekonečnem se můžeme setkat např. v situaci nějaké posloupnosti objekti̊, které v určité nejasné oblasti mění svou podstatu, jako napřr. posloupnost opičáků vyvíjejících se až k člověku (Vopěnka, 2008).

Poznamenejme ještě, že s obzorem se setkáváme ve dvou podobách. Jednak při pohledu do dálky, kdy se nám velmi početná množina může jevit jako nekonečná, a dále při pohledu do hloubky, kdy se nám může zdát nějaká množina nekonečná proto, že její prvky jsou neuchopitelné, nerozlišitelné. 
Např. Michal (15 let) u většiny položek dotazníku týkajících se mohutnosti reálných množin reagoval slovy: Nedaji se spočítat, těch je nekonečně. Stejně argumentoval i tam, kde by ono spočítání reálně proveditelné bylo (např. zrníčka písku na polévkové lžíci). Tato debata vznikla dotazem, je-li na celé zemi, poté v ČR, poté $\mathrm{v}$ jednom mraveništi nekonečně mnoho mravenců. Stejné to bylo u ryb v oceánech či např. u množiny všech atomů ve špendlíkové hlavičce. Při dotazu na počet všech lidí na světě však Michal říká: Těch je konečně mnoho, vždyt to se provádí, to je to sčitání domü, bytů a lidí. Michal svůj obzor překročil tím, že již slyšel o sčítání všech lidí na světě. Proto je pro něj tato množina konečná. Oproti tomu se množina všech ryb nebo mravenců i nadále táhne za jeho obzor, proto je pro něj nekonečná. Je pravděpodobné, že dalšími zkušenostmi Michal překročí i tento obzor a množina všech ryb či mravenců se pro něj stane konečnou, stejně jako množina všech lidí.

Avšak u množiny všech atomů bude muset překročit ještě další obzor, a to obzor nepředstavitelně malého. Proto je možné, že i po překonání obzorů souvisejících s obrovskými množinami bude Michal množinu všech atomů považovat za nekonečnou. V tomto kontextu navíc hraje podstatnou roli interference se znalostmi, které žáci postupně o atomech získávají. Dozvídají se totiž o jejich nesmírné titěrnosti, což může mít negativní důsledky právě pro přijetí faktu jejich konečnosti. Například studentka 3. ročníku gymnázia odpovídá: [Atomů] těch je nekonečně mnoho, protože jsou úplně malinký. V šetření (Cihlář et al., v tisku) uvedlo přibližně 50 \% maturantů, že molekul na Zemi je nekonečně mnoho!

Při porovnávání počtu všech atomů na Zemi a počtu všech úseček, jejichž středem je daný bod $A$, Michal ř́ká: Atomů je víc než těch úseček, atomů je jen tady třeba v týhle tužce několik miliard, to se ani nedá spočitat, těch je nekonečně. Ale těch úseček, tady na obrázku, to se dá spočítat, taky jich je hodně, podle toho, kolik jich nakreslíme, můžeme jich nakreslit nekonečně mnoho, ale zase těch atomů je na víc mistech nekonečně mnoho, to se spočítat nedá. Atomy nevidí, jsou malinkaté, neuchopitelné, jsou všude, svět se z nich skládá. Úsečky aspoň může kreslit, manipulovat s nimi. Množinu atomů chápe jako aktuálně přirozeně nekonečnou, ta množina existuje, netvoříme ji, zatímco těch úseček je pouze potenciálně nekonečně mnoho (může je kreslit stále, pořád, bez omezení). Intuitivně vnímá aktuálně přirozeně nekonečnou množinu početnější než množinu potenciálně nekonečnou.

Michal pracuje s přirozeným nekonečnem. Počet některých objektů je tak obrovský, že přesahuje jeho obzor. Atomy jsou nedosažitelné do hloubky, přímky do dálky, lidi jsou před obzorem, počet mravenců je za jeho obzorem. Učením se dalších poznatků o atomech nebo o mravencích se posune jeho obzor. V geometrickém světě je Michal na obzor a jeho překračování zvyklý, protože se učil o nekonečné délce př́mky nebo o nekonečném počtu bodů na ní, a tyto obory chápe jako klasicky potenciálně nekonečné; ale v reálném světě je obzorem omezen daleko více. Rozlišování mezi reálným a geometrickým světem je v historii matematiky přítomné až do doby Newtona, který geometrický eukleidovský prostor ztotožnil s naším reálným prostorem. Do té doby to byly dva různé světy. Eukleides se nesnažil o zdokonalení poznání rozvíjením poznatků napínačů provazů. Svědčí o tom jeho odklon od praktických problémů. On si klade otázku, jaký je součet vnitřních úhlů trojúhelníku. Tato otázka je pro napínače provazů bezpředmětná. Naproti tomu rozpůlit úsečku je pro provazonapínače hračkou, avšak Eukleidés hledá daleko náročnější řešení v rámci svých axiomů (Vopěnka, 2000). Tedy rozlišení mezi reálným a geometrickým světem je po dlouhou dobu vývoje matematiky jeho přirozenou součástí.

Michal rozlišuje mezi reálným a geometrickým světem, když odmítá porovnávat množinu všech mravenců na světě a množinu všech os souměrnosti kruhu a říká, že 
jde o reálné zaměrení a geometrické zaměrení. Marx (2006) použivá v této souvislosti ve své studii o představách žáků o nekonečných procesech termíny "Außenwelt" a „Mathematikwelt".

Jakub (11 let) rozumí nekonečné množině jako velmi velké množině, která přesahuje až za obzor jeho pohledu. S nekonečnem zachází jako s velmi velkým číslem, které se př́padně může ještě zvětšit. Na otázku experimentátora, zda je na Zemi konečně nebo nekonečně mnoho zrnek písku, Jakub odpovídá, že je jich nekonečně mnoho, přestože po chvíli říká, že se dají spočítat: No, kdybych měl dovolenou na hodně dlouho, tak je možná spočítám. Těch budou triliony, možná i víc.

Pro Jakuba nejsou jeho výpovědi ve sporu, protože rozumí nekonečné množině jako velmi velké množině, která přesahuje až za obzor jeho pohledu, je tedy přirozeně nekonečná. Jeho obzor je určován také tím, jaké číslo umí pojmenovat, takové si totiž umí nějakým způsobem představit. Avšak číslo jako trilion je již pro něj neuchopitelné, je to totéž jako nekonečno.

V kontextu nekonečného periodického rozvoje poodkrývá Klára (19 let) svou představu nekonečně velkého množství devítek $\mathrm{v}$ čísle $0, \overline{9}$ právě jako přirozeně nekonečného:

E183: Když říkáte, že $0, \overline{9}$ je menši než jedna, tak mi ted’ řekněte, jaký je rozdíl mezi tou jedničkou a mezi tím $0, \overline{9}$.

K184: (2) Tak tam je žádná celá řáká, já nevim kolik, milióntina, já nevim.

E185: Milióntina?

K186: No prostě, no neni to jedna desetina, je to menši než ta jedna desetina, mnohem menší.

E187: Tak jaký?

K188: (7) No těch devítek je tam víc, je to 0,99 nevim, kam až.

E189: Aha. Těch devítek $v$ tom rozvoji $0, \overline{9}$, kolik jich tam teda je?

K190: Nekonečně mnoho. (2) Ne, já nevim, je jich tam prostě hodně, strašně moc.

Klára jednoznačně pracuje s počtem devítek za desetinou čarou jako s konečným. Avšak doposud byla pro ni tato představa naprosto postačující. Ve všech úvahách, které prováděla, mohla beztrestně číslo $0, \overline{9}$ vždy nahradit jeho dostatečnou aproximací. Neměla proto důvod o své představě pochybovat. Poznamenejme ještě, že otázka typu Čemu se rovná rozdíl $1-0, \overline{9}$ ? je nástrojem pro navození kognitivního konfliktu, a tedy vytváří situaci, kdy jedinec může lépe překážku překonávat.

Vnímání obzoru, jeho posouvání a překračování hraje ve vývoji porozumění nekonečnu významnou roli. V různých podobách se (mnohdy skrytě) modely vystavěné na představě přirozeného nekonečna objevují jako překážky při utváření znalostí o klasickém nekonečnu, a to jak v jeho potenciální tak aktuální podobě. Potenciální vnímání nekonečna se stává překážkou v okamžiku, kdy je jedinec novým kontextem nucen potenciální přístup aktualizovat. V tuto chvíli by měl úplně zavrhnout obzor, který je přirozeným projevem potenciálního nekonečna. On to ale neudělá a přesune jej do jakéhosi „nevlastního bodu“, kde s ním již nelze posunovat.

\subsection{ZnALOSTI O KONEČNU}

Jevy popisované v předcházejících dvou paragrafech provázejí všechny překážky vycházející ze zkušeností s konečnem. Mnohá slova budu proto opakovat a často se odvolávat na princip tvůrce a polohu obzoru. Přesto je účelné zaměřit se na znalosti o konečnu explicite. Je totiž na místě očekávat, že znalosti o konečnu, tj. o konečných geometrických objektech, o konečných množinách a o konečných procesech, jsou překážkou pro znalosti o jednotlivých atributech nekonečna. Evidentní je to 
u platnosti Eukleidova axiomu Celek je větši než část, o jehož platnosti na konečných objektech máme bezpočet zkušeností. Není proto překvapivé, že bylo v historii tolikrát komentováno, že u nekonečných množin zachování tohoto pravidla neplatí, a proto nekonečné množiny nejsou možné.

Podobně nebylo nerozumné očekávat, že suma nekonečně mnoha kladných veličin musí růst nade všechny meze. Popřípadě, že spojením bezrozměrných bodů nelze vytvořit množinu, která má nenulovou míru. Dobře uspořádaná konečná množina má maximum a minimum, a proto jakákoli množina by maximum a minimum měla mít.

Jednoznačně tedy očekáváme, že zkušenosti nabyté manipulací s konečnými objekty (at̉ už matematickými nebo z běžného života) mají obecnou platnost. Proto bylo jejich nesplnění $\mathrm{v}$ historii vykládáno jako spor a tudíž bylo důvodem $\mathrm{k}$ zavržení aktuálního nekonečna. Často citovaným př́ikladem jsou úvahy, které provedl Galilei $^{6}$ a ve kterých objasňuje, že není možné porovnávat počet všech přirozených čísel a počet všech jejich druhých mocnin, a podobně nelze porovnat počet všech bodů na kratší a delší úsečce. Jistou analogií jsou Cantorovy marné pokusy dokázat, že množina bodů na čtverci má větší mohutnost než množina bodů na úsečce.

Na počátku školní docházky má žák zkušenosti pouze s konečnými množinami (zná malá přirozená čísla, pojem čísla mu splývá s počtem prvků konečné množiny). Setkává se pouze $\mathrm{s}$ nepř́lliš početnými množinami z reálného světa a na základě elementárních představ o „velikosti“ je umí intuitivně porovnávat (Maruška má víc bonbónů než já).

Později se setkává s více početnými množinami, učí se pojmenovávat počet jejich prvků, rozšiřuje si obor přirozených čísel o záporná, racionální a iracionální čísla, seznamuje se s číselnými operacemi. V geometrii se setkává s bodovými množinami, kterým přiřazuje míru a vnímá je jako omezené či neomezené.

Prvním reprezentantem nekonečných množin je pro žáky množina všech přirozených čísel. Nejprve je chápána (podobně jako přímka) jako „neomezeně prodlužovatelná“ (ke každému číslu existuje ještě větší číslo), tedy ve smyslu potenciálního nekonečna. Pozdější přijetí aktuální existence této množiny je spojeno též s akceptováním existence nekonečného procesu. Vytváření dalších pojmů spojených s nekonečnem podstatně závisí na tom, zda se vytvoří tato představa aktuálně nekonečné množiny přirozených čísel.

Znalosti o konečných množinách žáci neoprávněně přenášejí i do oblasti nekonečných množin. Mají problém odlišit velmi početné množiny, které jsou za jejich obzorem, tedy přirozeně nekonečné, od klasicky nekonečných množin. Jak již bylo řečeno, obvykle používají představu, že prvky konečné množiny „lze spočítat", a tedy nelze-li prvky množiny spočítat, prohlašují množinu za nekonečnou, tzn. používají princip tvůrce.

V kontextu geometrických bodových množin bývá pro studenty klíčovým kritériem pro porovnání jejich mohutností omezenost či neomezenost nositele uvažované množiny. Např́klad Pavel (13 let) říká: Mravencủ na Zemi není nekonečně mnoho, protože by se tam prece nevešli. Vždyt̉ každej přeci zabirá nějaký misto. Toto kritérium, které je správné u „reálných“ množin, selhává často u množin ze světa matematiky. V tomtéž rozhovoru Pavel později říká: Na té úsečce nemůže být nekonečně mnoho bodi̊, když je jen $2 \mathrm{~cm}$ dlouhá.

Následující ukázka z rozhovoru ukazuje, jak se u některých respondentů přirozeně uplatňuje představa omezenosti množiny:

\footnotetext{
${ }^{6}$ Galileo Galilei Distorsi e dimonstrazioni matematiche, interno a due nuove scienze, 1638.
} 
Matěj (15 let) má porovnat mohutnost tří bodových množin - množinu všech bodů úsečky délky $10 \mathrm{~cm}$, množinu všech bodů kružnice o poloměru $10 \mathrm{~cm}$ a množinu všech bodů přímky.

E18: Tak, Matěji, ty jsi u téhle otázky uvedl, že těch bodů je ve všech těch třech množinách nekonečně mnoho. A mě by ted’ zajimalo, jestli bys je uměl porovnat, ríct, kde jich je nejvíc.

M19: Na tý př́mce jich je nejvíc.

E20: Jo? A na tý úsečce a kružnici?

M21: Na tý úsečce a kružnici jich je taky nekonečně mnoho, ale na př́mce jich je nejvíc.

E22: A je jich víc na tý úsečce, nebo na tý kružnici?

M23: To se nedá porovnat, tady jich je nekonečně mnoho a tady jich je taky nekonečně mnoho, to se nedá spočítat (ukazuje tužkou na obrázek kružnice a úsečky).

E24: Aha, a na tý př́mce se to snad dá spočítat? Nebo proč myslíš, že je jich tam nejvic?

M25: No ta př́mka nikde nekončí, ta vede furt dál, ale (4) ta úsečka nebo ta kružnice, ty jsou tady (ukazuje opět tužkou před sebe na obrázek kružnice a úsečky).

Matěj používá dvě kritéria pro porovnávání nekonečných množin - kritérium celek-část (M19) a kritérium neporovnatelnosti (M23) nekonečných množin. Kritéria porovnávání nekonečných množin popisují ve svých výzkumech podrobně Tsamir a Tirosh (1996). Jimi popisovaná kritéria vlastní podmnožina obsahuje méně prvkư, všechny nekonečné množiny maji stejný počet prvkü a nekonečné množiny nelze porovnávat spolu s kritériem počet disjunktních alespoñ dvouprvkových množin je menši než počet prvků jejich sjednocení jsou překážkami, které vycházejí ze znalostí o konečných množinách.

Znalosti o konečnu se neprojevují jako překážky jen v kontextu mohutností množin. Typickým př́kladem v geometrickém kontextu je chápání př́imky jako namalované, tedy konečné čáry. Např́klad Vendulka (9 let) odpovídá na otázku, která z polopřímek na obrázku 1 je delší, že delši bude to béčko, protože začíná o kousek dřiv, nebot ztotožňuje polopřímku s jejím sestrojeným obrazem. Ačkoli Jan (18 let) v následujícím rozhovoru uvažuje o polopřímce jako o nekonečné, a to v potenciálním smyslu, zkušenost s konečnými objekty mu zabraňuje přijmout důsledky vlastních úvah:

E5: Tady jsou dvě polopř́mky a a b (ukazuje na obrázek 1). Je některá z nich delší a pokud ano, tak která?

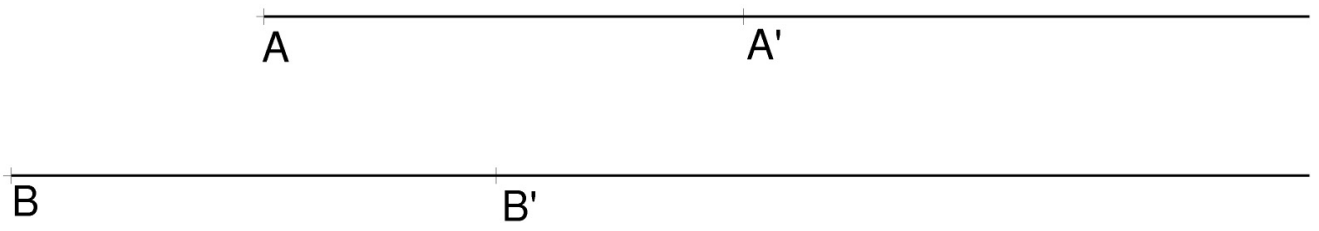

Obr. 1

J6: No tak, (1) ty př́mky nikde nekončej, nebo ty polopř́mky nikde nekončej, takže (3) nedalo by se určit, která je delši. Ale kdyby bylo daný, prostě, kde to nekonečno je nebo kde to nekonečno konči (směje se) nekonečno končí, prostě, kde by se nacházelo to nekonečno, tak by byla delši ta b. Ale vlastně nekonečno daný není, takže se to nedá určit, polopřimka, která je delší.

E11: A kdybych posunula tu polopř́mku a takhle? (pokládá doplňující otázku, která by měla navodit kognitivní konflikt, nebot stejnou úvahou lze dojít k tomu, že nyní jsou polopřímky stejně dlouhé, případně je delší polopřímka $\left.A A^{\prime}\right)$. 
J12: Že to pokračuje, pokračuje pořád a pořád dál, takže by obě byly stejný. Nebo stejný, teoreticky stejný, protože může může pokračovat, (2) neni dán konec, takže nemůžeme, nemůžeme ř́ct, která je delši. Zase, kdyby byl ten konec dán, tak (1) tak by byla delši $a$.

Jan rozhodně nezaměňuje přímku s jejím obrazem, chápe polopřímku jako potenciálně nekonečně dlouhou - tedy neomezeně prodlužovatelnou, a proto nemůže určit, která z polopřímek je delší. Avšak když se pokusí nekonečnost polopřímky aktualizovat, projeví se znovu znalosti o konečnu - ta, která „začíná“ dříve, musí být delší (J6, J12).

Janův způsob uvažování není vůbec překvapující. Vlastně stejně by odpověděl i Bolzano. Vzhledem k tomu, že ve svém axiomatickém systému zachoval Euklidův axióm Celek je větší než část na úkor axiómu Co se navzájem kryje, rovno jest, porovnává nekonečné množiny rozdílně oproti Cantorovi. „Uvádí př́íklad dvou polopřímek ze dvou různých bodů $A$ a $B$, které leží na stejné přímce a které běží na stejnou stranu, a tvrdí, že jedna z nich je větší o úsek $A B$. Přímka, na níž polopřímky leží, je opět větší, a to o veličinu, která je nekonečná, než obě polopřímky“ (Trlifajová, 2001, s. 24).

Znalosti o konečnu se jako překážka projevují i v řešení úloh o porovnávání čísel $0, \overline{9}$ a 1 . Respondenti, bez ohledu na věk (mnohdy i učitelé v praxi), nejčastěji odpovídají, že $0, \overline{9}<1$. Mnozí to pak vysvětlují na základě znalosti o tom, jak porovnávat desetinná čísla s ukončeným desetinným rozvojem, tzn. porovnáváním číslic na jednotlivých pozicích. Stejný postup volí i pro číslo periodické, a protože se liší hned na první pozici, nemohou být čísla stejná, i když je v periodickém rozvoji nekonečně mnoho devítek.

Taková čísla, jako je $0, \overline{9}$, neměla v matematice dlouho místo. Legitimně mohla být přijata až s infinitesimálním počtem, kdy bylo řečeno, co se myslí součtem nekonečné řady. Napřr. Bolzano váhal s přijetím rovnosti mezi čísly $0, \overline{9}$ a 1 . Znamenalo by to ale rozbití kontinua - množiny reálných čísel - a proto rovnost přijal.

Další překážkou spadající do oblasti znalostí o konečnu je znalost, že každá uspořádaná množina má minimum i maximum. To platí pouze pro konečné množiny, ale je-li znalost přenesena na množiny nekonečné, selhává. Michal (15 let) například připouští, že ke každému přirozenému číslu existuje následovník, ale nevyplývá pro něj z toho nutně, že největší přirozené číslo neexistuje, je naopak přesvědčen o jeho existenci:

E51: Jaké číslo je největši? Ty jsi tady v dotazníku napsal tohle, ležatou osmičcu. M52: No, nekonečno.

E53: Hm. (3) Hele, Michale, znáš nějaký hodně velký přirozený číslo?

M54: Já nevím, třeba (4) miliarda.

E55: A existuje ještě nějaký větší než miliarda?

M56: Jo, miliarda trí milióny.

E57: A ještě nějaký většı?

M58: No, jasně, vždycky můžu to číslo ještě zvětšit, třeba jen o jedničku.

E59: Počkej počkej, to je divný. Když můžu každý čislo vždycky ještě zvětšit, tak jak může být potom to nekonečno největšr?

M60: No může, za ním už nic není.

Pro Michala je tedy nekonečno největším číslem, které má určité vlastnosti přirozeného čísla, ale ta vlastnost, že může být zvětšeno, mu už chybí. Nekonečno je vlastně pro něj posledním číslem, tj. posledním obzorem, ke kterému přirozená čísla směřují. 


\section{ZÁVĚR}

Vývoj představ jedinců o nekonečnu koresponduje do značné míry s fylogenetickým vývojem. Ve svých výpovědích respondenti užívají slova nekonečno, nekonečně či nekonečně mnoho. Těmto slovům může ale respondent přisuzovat nejrůznější obsah a význam. Představy, které vedou k těmto odpovědím, úzce souvisejí s pojmem obzoru, jeho polohou a postupným překonáváním různých obzorů. Výsledná vývojová struktura obsahuje čtyři typy představ, přitom poslední z nich je klasické aktuální nekonečno, které odpovídá představám současné (školské) matematiky. Popsanou klasifikaci však nelze vnímat natolik zjednodušeně, že respondent má jedinou představu nekonečna ve všech kontextech. Právě naopak, a ve světle teorie epistemologických překážek je snadno pochopitelné, že se jedinec nejrůzněji vrací ke svým dřivějším (a naivnějším) představám.

Nejjednodušší a nejranější představa o nekonečnu, s níž se u studentů setkáváme, je přirozené nekonečno. Přirozené nekonečno je jev subjektivní - jedinci se mohou nějaká množina nebo objekt jevit přirozeně nekonečnými, jestliže se táhnou až k jeho obzoru. Budeme-li chápat množiny jako klasicky aktuálně nekonečné, pak jedincův obzor leží v jejich rámci a je pevný. Např́ílad přirozená čísla jsou v jeho představě ukončena největším pevným přirozeným číslem (např. trilion apod.). Přímka je v jeho představě ztotožněna se svým obrazem - úsečkou. O čísle $0, \overline{9}$ prohlašuje, že devitek za desetinnou čárkou je nekonečně mnoho, ale znamená to pro něj přirozeně nekonečně mnoho, takže pracuje vždy jen s nějakou konečnou aproximací čísla $0, \overline{9}$.

Pokročilejší představa je potenciální nekonečno. Student si již uvědomuje možnost, že libovolný obzor může být překročen. Jeho obzor je tedy pohyblivý, ale stále leží v rámci diskutované množiny chápané námi klasicky aktuálně. Přirozená čísla jsou v jeho představě stále ukončena největším přirozeným číslem, o kterém ale nevíme, jak je veliké. Přímka je zde chápána jako neomezitelně prodloužitelná úsečka v Eukleidově smyslu. $\mathrm{V}$ úlohách o číslech $0, \overline{9}$ a $1-0, \overline{9}$ je i zde v představě studenta mezi desetinnou čárkou a poslední devítkou, resp. jedničkou, z našeho pohledu konečně mnoho cifer (to se projeví například při diskusi o desetinásobku tohoto čísla), ale pohyblivost obzoru se projevuje procesuálním chápáním počtu cifer, tedy že libovolný jejich počet může být zvětšen. Místo obrovského pevného čísla (trilion apod.) se často objevují formulace Je jich strašně moc, nevíme ale, kolik jich vlastně je. Rozdíl mezi představou popsanou slovy Přirozené nekonečno a Potenciální nekonečno se jasně projevuje např. v úloze o existenci průsečíku různoběžných přímek, jejichž obrazy na papíru se neprotínají. Zatímco student s představou přirozeného nekonečna existenci průsečíku odmítne, student s představou potenciálního nekonečna obrazy přímek prodlouží a existenci průsečíku potvrdí.

Zajímavým fenoménem je představa, kterou vystihuje termín pozice omega. Vzniká u některých žáků a studentů tam, kdy se snaží aktualizovat svůj potenciální přístup k nekonečnu. Například množina přirozených čísel je prodloužena o jakési „nevlastní“ přirozené číslo, které je větší než všechna ostatní přirozená čísla. Toto číslo (respondent ho nazývá nekonečno) sice má některé vlastnosti čísel - například označuje počet prvků nějaké množiny, ale některé vlastnosti mu chybí - například možnost sečíst ho s jiným číslem. Č́slo $0, \overline{9}$ je pak chápáno tak, že devítek za desetinnou čárkou je (aktuálně) nekonečně mnoho, ale za nimi je ještě jedna poslední. Č́slo $1-0, \overline{9}$ je uvažováno ve tvaru $0,00 \ldots 01$, kde mezi desetinnou čárkou a jedničkou je (aktuálně) nekonečně mnoho nul. Podobně přímka je prodloužená až „do nekonečna“, přičemž si ale stále zachovává svo̊j krajní (nevlastní) bod. Pozici omega lze chápat jako vývojový mezistupeň mezi potenciálním a aktuálním chápáním neko- 
nečna. Respondent svůj obzor, který je přirozeným projevem potenciálního přístupu, nezruší úplně, ale přesouvá jej do jakési nevlastní polohy, kde s ním již nelze posunovat.

S tím, jak se posunuje jedincův obzor, neodmyslitelně souvisí pojetí existence matematických objektů. Totiž podle toho, kdo je uskutečňovatelem nějakého objektu, kdo je zárukou jeho existence, zda člověk, nadčlověk či Bůh, tam nacházíme, resp. nenacházíme žádný, pomyslný obzor. Děti na počátku učebního procesu přistupují k jevům naprosto subjektivně. Přisuzují existenci těm objektům, které mohou evidovat tělesnými smysly, a to bezprostředně. Postupně přijímají existenci takových objektů, znají-li alespoň principielní možnost jejich vytvoření - konstrukci nějakého geometrického objektu, dopočítání se nějakého velkého čísla apod. Na konci tohoto procesu je ztotožnění se současným množinovým pojetím matematiky.

Sama matematika prodělala tento vývoj k absolutnímu zaštitovateli pravdy velmi pozvolna, což můžeme mimo jiné dobře pozorovat na přisuzování existence geometrickým objektům. Za pomoci teorie množin je totiž možné přímku chápat jako množinu bodů, ze kterých se tato přímka skládá. Najednou se geometrický prostor zaplnil nejrůznějšími objekty, které byly v předmnožinové matematice nemyslitelné, z nichž úsečka bez koncových bodů nebo kruh bez hraniční kružnice jsou ty nejjednodušší. Koncem 19. století se pak zrodilo nové odvětví geometrie - topologie. Ta se dívá na roztodivné množiny bodů jako na geometrické objekty a především tak vnímá i doplňky k takovým geometrickým objektům.

Zdálo by se, že geometrie, kterou dnes vyučujeme na našich školách, alespoň základních, odpovídá vývojově právě Eukleidovu pojetí. Ovšem ačkoli pracujeme stále v Eukleidově geometrii, nebớ je to model teorie jeho pěti postulátů, naše pojetí je značně ovlivněno pozdějším vývojem, především myšlenkami teorie množin. Často když čteme samotného Eukleida, si obsah jeho slov vykládáme prostřednictvím teorie množin. Tento obrovský krok, který lidstvo započalo již v době Galilea, dokončil David Hilbert, když provedl axiomatickou výstavbu geometrie a mimo jiné vyslovil axiom úplnosti pro body, př́mky a roviny. Od této chvíle byl geometrický prostor a priori vyplněn všemi body, všemi přímkami a všemi rovinami (tedy i jejich částmi). Geometr od této chvíle nevytváří geometrické útvary, ale pouze si je, jejich vlastnosti a vztahy „uvědomuje“.

Je zřejmé, že z této disproporce „ideální školské matematiky“ a přirozeného př́istupu žáků v podobě principu tvůrce mohou vznikat mnohá nedorozumění a docházet $\mathrm{k}$ fixacím nesprávných představ. Učitel si tak musí být vědom toho, odkud a kam chce dovést své žáky, a neustále vytvářet situace vhodné k překonávání jednotlivých epistemologických překážek.

\section{LITERATURA}

BROUSSEAU, G. Theory of Didactical Situations in Mathematics. Didactique des mathématiques, 1970-1990. [Balacheff, N. et al.(ed.)] Dordrecht : Kluwer Academic Publisher, 1997.

BROUSSEAU, G.; SARRAZY, B. Glossaire de quelques concepts de la théorie des situations didactiques en mathématiques. DAEST, Université Bordeaux 2, 2002. (English translation by V. Warfield).

CIHLÁ̌̆, J.; EISENMANN, P.; KRÁTKÁ, M.; VOPĚNKA, P. Cognitive conflict as a tool of overcoming obstacles in understanding infinity. Teaching Mathematics and Computer Science, 2009, Vol. 7, No. 2, p. 279-295. 
CIHLÁR̆, J.; EISENMANN, P.; KRÁTKÁ, M. The Process of the Infinity Concept Formation by means of Obstacles and Their Overcoming. [v tisku].

EUKLEIDES. Základy. Knihy I-IV. [Komentované P. Vopěnkou. Překlad F. Servít, 1907.] Nymburk : OPS, 2007.

FISCHBEIN, E.; TIROSH, D.; HESS, P. The Intuition of Infinity. Educational Studies in Mathematics, 1979, Vol. 10, p. 3-40.

JELEMENSKÁ, P.; SANDER, E.; KATTMANN, U. Model didaktické rekonštrukcie: Impulz pre výzkum v oborových didaktikách. Pedagogika, 2003, roč. 53. č. 2, s. $190-201$.

JIROTKOVÁ, D.; LITTLER, G. Student's Concept of Intimity in the Context of a Simple Geometrical Construct. In Proceedings of the 2003 Joint Meeting of PME and PMENA, (Vol. 3, p. 125-132), Honolulu, Hawai, 2003.

KAPADIA, R.; BOROVCNIK, M. Chance Encounters: Probability in Education. Dordrecht : Kluwer Academic Publishers, 1991.

KRÁTKÁ, M. Srovnání ontogenetického a fylogenetického vývoje porozumění jevu nekonečno v geometrickém kontextu. Praha, 2009, 150 s. Disertační práce (Ph.D.). Univerzita Karlova v Praze. Pedagogická fakulta. Katedra matematiky a didaktiky matematiky. Vedoucí disertační práce P. Vopěnka.

MARX, A. Schülervorstellungen zu „unendlichen Prozessen“. Berlin : Verlag Franzbecker, 2006.

RADFORD, L. On Psychology, Historical Epistemology, and the Teaching of Mathematics: Towards a Socio-Cultural History of Mathematics. For the Learning of Mathematics 17, 1. Vancouver : FLM Publishing Association, 1997, p. 26-33.

RADFORD, L.; BOERO, P.; VASCO, C. Historical formation and student understanding of mathematics: Epistemological assumptions framing interpretations of students understanding of mathematics. In FAUVEL, J.; Van MAANEN, J. (ed.). History in Mathematics Education. Dordrecht, Boston, London : Kluwer, 2000.

SIERPINSKA, A. Understanding in Mathematics. Washington, D.C. : The Falmer Press London, 1994.

SPAGNOLO, F.; ČIŽMÁR, J. Komunikacia v matematike na strednej škole. Brno : Masarykova univerzita, 2003.

TRLIFAJOVÁ, K. Studie o nekonečnu v matematice. Praha : 2001. Disertační práce (Ph.D.). Univerzita Karlova v Praze. Matematicko-fyzikální fakulta. Katedra teoretické informatiky a matematické logiky.

VOPĚNKA, P. Pojednání o jevech povstávajících na množství. Plzeň a Nymburk : OPS, 2008.

VOPĚNKA, P. Úhelný kámen evropské vzdělanosti a moci. Praha : Práh, 2000.

Magdalena Krátká - E-mail: magdalena.kratka@gmail.com

Univerzita J. E. Purkyně v Ústí nad Labem, Př́rodovědecká fakulta, Česká republika 